\title{
The Effect of Giving A Compress of Sirih Leaves Boiled Water on The Level of Scabies
}

\author{
Eva Dwi Ramayanti*, Satria Eurika Nurseskasatmata \\ Departemen of Nursing Science, University Of Kadiri Kediri, Indonesia \\ *rama.yanti71@yahoo.com
}

\begin{abstract}
Scabies is a type of skin disease that often attacks santriwati. Preliminary survey data 16 out of 20 santriwati complain of tingkat scabies, 18 out of 20 santriwati likes to say that have never been exposed to tingkat scabies. 16 out of 20 santriwati interviewed said they still feel itching at night time. From the data above shows that there are still many students who have level of scabies. The purpose of this study is to know the influence of compression of betel leaf boiled water to level scabies at santriwati in boarding school as-salam turjak village on the island kangean madura in 2019. This research is Pre Experimental. The population in this study are all santriwati who experience tingkat scabies in PP As-Salam Kangean Island in 2019 with the number of 21 people. Sample 18 respondents based on Simple Random Sampling technique. The test used is wilcoxon.

The result of the research can be interpreted that before the compress of betel leaf water, santriwati has level scabies stage 3 at pre-test $(55,6 \%)$ and after therapy compress boiled water of betel leaf santriwati experience Tingkat scabies stage $2(61,1 \%)$. Based on Wilcoxon test, p-value is 0.000 , because p-value $<\alpha(0.05)$ then $\mathrm{H} 0$ is rejected and $\mathrm{H} 1$ is accepted which means there is influence of compression of boiled water of betel leaves to level scabies santriwati, it is found that the test result is Negative rank Meaning between before and after given Compost Water Supply boiled betel leaves there is a decrease in level scabies santriwati. Is expected to increase the knowledge of responden in preventing and lowering scabies an can improve the quality of health.
\end{abstract}

Keywords: Scabies, Water Compress Boiled Betel Leaves, Pre Experimental 


\section{STRADA Jurnal Ilmiah Kesehatan}

DOI: $10.30994 /$ sjik.v9i2.494

ISSN: 2252-3847 (print); 2614-350X (online)

Vol.9 No.2 November 2020 Page.1552-1557

\section{BACKGROUND}

Santriwati is a vocation given to women who study and seek religious knowledge in Islamic boarding schools and remain as santriwati whose morals are different from those of women who do not live in the pesantren. One of the health problems that often arise in santriwati is skin health or what often occurs is scabies. Scabies (scabies) is a type of skin disease. Scabies is an itchy skin disease that can be contagious. Scabies is not a lice infection, tiny mites called sarcoptes scabies build their nests in the outer layer of human skin. Because they lay their eggs in the skin, these ticks can cause non-stop itching and eventually red bumps. Scabies skin disease is also a contagious disease. This disease can be transmitted directly (skin-to-skin contact), for example, shaking hands, sleeping together, and through sexual contact. Transmission indirectly (through objects), for example clothes, towels, sheets, pillows and blankets. The prevalence of scabies (scabies) can affect all ages, races, and socioeconomic levels. About 300 million cases of scabies worldwide are reported each year. According to the Indonesian Ministry of Health, based on data from health centers throughout Indonesia in 2008, the incidence of scabies was 5.6\% - 12.95\%. Scabies in Indonesia ranks three out of the twelve most common coolie diseases.

According to medical records at the Pondok Pesantren As-salam Clinic, the number of cases of scabies in 2006 was $45(10.37 \%)$ sufferers. There was an increase in 2007 as many as 79 (18.20\%) and in 2008 as many as $74(17.05 \%)$ patients. The number of cases of scabies in 2009 was 82 (18.89\%) sufferers (As-Salam Islamic Boarding School Health Center, 2009). Survey data which was conducted on December 1, 2016 at the As-salam Islamic boarding school for 80 students were randomly taken, some 21 people were known that the students complained of scabies, 5 of the 21 students complained of itching. 16 out of 21 santriwati interviewed said they still felt itchy at night. And 16 of them complained that they still felt itchy at night. The data above shows that there are still many female students who have scabies.

The cause of scurvy is caused by a type of lice or mite which can cause scabies, baldness, and itching on the skin. When it gets into this layer of skin, the lice will lay eggs and reproduce and can last for months or even years.

The impact of skin diseases (scabies), which tends to be contagious, is not handled properly and correctly: itching and discomfort increases continuously, increases the risk of transmission to family members and other friends, damage to skin tissue, disturbances / obstacles in carrying out activities. daily, health problems may also increase (impaired resting needs fulfillment).

The solution to dealing with the skin disease (scabies) is to take treatment with traditional and natural medicines, namely by using medical and non-medical,: from medical is to use antibiotics, from non-medical namely by using betel leaf, how to use it include: 10 pieces of green betel leaves, wash with running water until clean, heat 2.5 liters of water in a waiting pot until the water is boiling, put the betel leaves in boiling water for 3-5 minutes, let stand and wait for the water to become warm. compress container on the wound (scabies) do compressing the betel leaf for 7 days ( 1 week) do it twice a day consecutively every morning and evening (morning 07.00, afternoon 14.00).

Based on this background description, the researchers are interested in researching "The effect of giving a compress of betel leaf boiled water on scabies to female students at the As-Salam Islamic Boarding School, Turjak Village on Kangean Island, Madura in 2019" 


\section{STRADA Jurnal Ilmiah Kesehatan}

DOI: $10.30994 /$ sjik.v9i2.494

ISSN: 2252-3847 (print); 2614-350X (online)

Vol.9 No.2 November 2020 Page.1552-1557

\section{METHOD}

The design used in this study is based on the scope of research, including the type of inferential research. Based on the place of research, including the type of field research. Based on the method of data collection, it is an observational research type. Based on the presence or absence of treatment, including the type of pre-experimental research with the One Group Pre Test Post Test Design approach. Based on the research objectives, including the type of treatment research. Based on data sources, including the type of primary research. The population in this study were 21 students who experienced scabies at the As-salam Islamic boarding school in Tturjak Village on Kangean Island, Madura in 2019, with a total sample of 21 people. The sampling technique used in this study was random sample. The research material used in this study was betel leaf stew extract. The data was collected by measuring the scabies stage before and after the intervention was given to each sample. Furthermore, the data obtained is written on the observation sheet. This research was conducted at the As-salam Islamic Boarding School, Turjak Village on Kangean Island, Madura, 18 November-March 2019. After obtaining approval from the Institute of the Faculty of Health Sciences, Kadiri University, he continued to ask permission from the Dean of the Faculty of Health Sciences, Kadiri University, then the researchers conducted a survey at the research location, after In collaboration between researchers and health authorities, the researchers asked for data on hypertension sufferers according to the sample criteria. Researchers measured the scabies stage of the students to meet the number of research samples. Previously, the sample was explained about the procedure and research objectives, then the sample signed informed consent. Then tell that the researchers will give celery juice every other day in the morning and do it for 2 times a week. Data were collected by assessing the scabies stage of the respondents before and after the intervention was given. Then the results were collected and recorded in the observation sheet, to determine if there was a change in the scabies stage of the respondent during the therapy session.

\section{RESULT}

Based on research, the following data were obtained:

1. General Data

a. Ditribusi responden on age

\begin{tabular}{ccc}
\hline AGE & F & $\%$ \\
\hline $11-18$ tahun & 2 & 11,1 \\
$15-17$ tahun & 12 & 66,7 \\
$18-21$ tahun & 4 & 22,2 \\
\hline Total & & 100 \\
\hline
\end{tabular}

b. Distribusi responden on higiene (going bath)

\begin{tabular}{ccc}
\hline Going bath per day & $\mathrm{F}$ & $\%$ \\
\hline once & 0 & 0 \\
twice & 7 & 38,9 \\
more & 11 & 61,1 \\
\hline Total & & 100 \\
\hline
\end{tabular}




\section{STRADA Jurnal Ilmiah Kesehatan}

DOI: $10.30994 /$ sjik.v9i2.494

ISSN: 2252-3847 (print); 2614-350X (online)

c. Distribusi responden on chages chlotes

\begin{tabular}{ccc}
\hline Chages chlotes & f & $\%$ \\
\hline Once & 18 & 100 \\
Twice & 0 & 0 \\
More & 0 & 0 \\
\hline Total & & 100
\end{tabular}

2. Special Data

a. Insiden scabies before treatment

\begin{tabular}{ccc}
\hline Kategori & Scabies before treatment & \\
\hline & $\mathrm{f}$ & $\%$ \\
Stadium 1 & 0 & 0 \\
Stadium 2 & 6 & 33,3 \\
Stadium 3 & 10 & 55,6 \\
Stadium 4 & 2 & 11,1 \\
\hline Total & 18 & 100 \\
\hline
\end{tabular}

b. Insiden scabies after treament

\begin{tabular}{ccc}
\hline Kategori & \multicolumn{3}{c}{ Scabies sesudah terapi } \\
\hline & F & $\%$ \\
\cline { 2 - 3 } Stadium 1 & 6 & 33,3 \\
Stadium 2 & 11 & 61,1 \\
Stadium 3 & 1 & 5,6 \\
Stadium 4 & 0 & 0 \\
\hline Total & 18 & 100 \\
\hline
\end{tabular}

c. Data of influence treatment on scabies

\begin{tabular}{|c|c|c|c|c|c|c|c|c|c|}
\hline \multirow{11}{*}{$\begin{array}{l}\text { Pre test } \\
\text { scabies }\end{array}$} & \multicolumn{9}{|c|}{ Post test Scabies } \\
\hline & \multirow[t]{2}{*}{ Kategori } & \multicolumn{2}{|c|}{ Stadium 1} & \multicolumn{2}{|c|}{ Stadium 2} & \multicolumn{2}{|c|}{ Stadium 3} & \multicolumn{2}{|c|}{ Total } \\
\hline & & $\mathrm{f}$ & $\%$ & $\mathrm{~F}$ & $\%$ & $\mathrm{f}$ & $\%$ & $\mathrm{~F}$ & $\%$ \\
\hline & Stadium 2 & 6 & 33,3 & 0 & 0 & 0 & 0 & 6 & 33,3 \\
\hline & Stadium 3 & 0 & 0 & 10 & 55,6 & 0 & 0 & 10 & 55,6 \\
\hline & Stadium 4 & 0 & 0 & 1 & 5,6 & 1 & 5 & 2 & 11,1 \\
\hline & & & & & & & ' & & \\
\hline & Total & 6 & 33,3 & 11 & 61,1 & 1 & 5 & 18 & 100 \\
\hline & & & & & & & 6 & & \\
\hline & p-value & & & 000 & & & & & \\
\hline & $: 0,05$ & & & & & & & & \\
\hline
\end{tabular}

\section{DISCUSION}

Insiden Scabies before treatment

Scabies before being given a compress of betel leaf boiled water at the As-salam Islamic Boarding School in Turjak Village, Kangean Island, Madura, it can be interpreted that most of the respondents $(55.6 \%)$ had stage 3 Scabies at the time of pre-test.Scabies is an 


\section{STRADA Jurnal Ilmiah Kesehatan}

DOI: $10.30994 /$ sjik.v9i2.494

ISSN: 2252-3847 (print); 2614-350X (online)

Vol.9 No.2 November 2020 Page.1552-1557

infestation of human skin caused by the penetration of an obligate parasite, namely S. scabiei var hominis into the epidermis (Stone et al., 2008). Scabies is caused by S. scabiei, which is transmitted by a fertilized female tick. Lice can live outside the skin for only 2-3 days at room temperature $210 \mathrm{C}$ with a relative humidity of $40-80 \%$. The female fleas are $0.3-0.4$ microns in size, the male fleas fertilize the female fleas and then die, then these female fleas will dig a hole into the epidermis and then make a tunnel in the stratum corneum, and lay their eggs in the tunnel (Harahap, 2009 ).Santriwati is a vocation given to women who study and seek religious knowledge in Islamic boarding schools and live as santriwati who have different morals from women who do not live in the pesantren.

\section{Insiden Scabies After treatment}

Scabies after being given a compress of betel leaf boiled water at the As-salam Islamic Boarding School in Turjak Village, Kangean Island, Madura, it can be interpreted that most of the respondents $(61.1 \%)$ experienced Stage 2 Scabies. The eugenol content in betel leaf has antifungal properties. Betel leaf, which has been known since $600 \mathrm{BC}$, contains antiseptic substances that can kill bacteria so that it is widely used as antibacterial and antifungal. this is due to the phenol derivative kavikol in its antiseptic properties, which is five times more effective than ordinary phenol. With its antiseptic properties, betel is often used for healing foot wounds due to nosebleeds and vaginal scabies (Atni, 2010)

Based on the above research, the researchers concluded that betel leaf boiled water is a concoction that has been made as an herbal medicine. Betel leaf is a herbal or medicinal plant that can be consumed directly by chewing it or making a stew for drinking. The decoction of the betel leaf itself is usually used as a medicine to cure diseases. It can be concluded that the betel leaf boiled water is effective in reducing the incidence of scabies experienced by santriwati. Cross tabulation of Scabies between before and after giving a compress of boiled betel leaf water at the As-salam Islamic Boarding School in Turjak Village, Kangean Island, Madura in 2019

\section{The influence of treatment to insiden scabies}

Scabies between before and after being given a compress of water with boiled betel leaf at the As-salam Islamic Boarding School in Turjak Village, Kangean Island, Madura, it can be interpreted that most respondents at the pre-test had stage 3 Scabies but after therapy the respondent had stage 2 Scabies, which was 10 (55.6\%) in PP As-salam in Turjak Village, Kangean Island, Madura in 2017. Based on the Wilcoxon test, the p-value was 0.000, because the p-value $<\alpha(0.05)$ then $\mathrm{H} 0$ was rejected and $\mathrm{H} 1$ was accepted, which means There is an effect of giving compresses of betel leaf boiled water to students' Scabies, it was found that the test results were Negative rank, which means that between before and after giving the compress of betel leaf boiled water, there was a decrease in Scabies in santriwati (Anne, 2001).

Betel leaf contains astiri oil where the main component consists of phenol and its derivative compounds such as kavikol, kavebetol, karvacol, eugenul, and allilpyrocatechol. Apart from essential oil, betel leaf also contains carotene, tiamen, riboflavin, nicotinic acid, vitamin $\mathrm{C}$, tannins, sugar, starch and amino acids. Betel leaf, which has been known since $600 \mathrm{BC}$, contains antiseptic substances that can kill bacteria so that it is widely used as antibacterial and anti-fungal. this is due to the phenol derivative kavikol in its antiseptic properties, which is five times more effective than ordinary phenol. With its antiseptic properties, betel is often used for healing foot wounds due to nosebleeds and vaginal scabies (Atni, 2010). 


\section{STRADA Jurnal Ilmiah Kesehatan}

DOI: $10.30994 /$ sjik.v9i2.494

ISSN: 2252-3847 (print); 2614-350X (online)

Vol.9 No.2 November 2020 Page.1552-1557

\section{CONCLUSION}

Scabies Before therapy, it can be interpreted that most of the respondents (55.6\%) had stage 3 scabies at the time of pre-test.Scabies After therapy, it can be interpreted that most of the respondents $(61.1 \%)$ experienced stage 2 scabies. There is an effect of giving water compresses boiled betel leaf on scabies to students at the As-salam Islamic boarding school on Kangean Island in 2019

\section{REFERENCES}

Amandeep K., Preksha S. M., Dirya S. 2015. The Effectiveness of Abdominal Breathing Exercises on Blood Pressure in Hypertension Patients. International Journal of Therapeutic Applications, Volume 24, 2015. 39-49

Anne, Rigaud. 2001. Hypertension in older eldely. The Journal of Gerontology. The Journals of Gerontology: Series A, Volume 56, Issue 4, 1 April 2001, Pages M217M225, https://doi.org/10.1093/gerona/56.4.M217

Arief Mansjoer. (2010). Kapita Selekta Medicine, 4th Edition, Jakarta: Media Eaculapius.

Amanda, C.G. (2017) Analyze the concept of self-management behavior and its implications are research and policy. Boston: University of Massachusetts Boston. (http://www.nursinglibrary.org/vhl/bitstream/10755/335260/1Green\%2C+Amanda++ A+Concept+Analysis+of+self-manajemet.pdf). Accessed on July 25, 2020 at 05.00 WIB.

Aulia Sani. (2012). Current Perspectives on Hypertension.PT. Medya Crea. Jakarta.

Breathesy, (2017). Blood pressure reduction: Frequently asked questions, http: www.control-your-blood-pressure.com/fag.html. accessed 15 September 2019.

Bruner \& Sudarth (2013). Medical-Surgical Nursing. Jakarta: EGC

Currie, Rigaud (2018). Blood Presure Target in Elderly. Journal of Hypertension: February 2018 - Volume 36 - Issue 2 - p 234-236 doi: 10.1097/HJH.0000000000001576

Dalimantra. 2011. Care Your Self, Hypertension. Publisher Plus. Jakarta.

Darmojo, R. (2012). Geriantri Textbook (Elderly Health Sciences), 4th edition, Jakarta: FKUI.

DEPKES RI. 2013. Hypertension Data. Ministry of Health RI: Jakarta

JATIM Provincial Health Office. 2019 Hypertension Case in East Java. East Java Provincial Government. Surabaya.

Frownfelter, D. \& Dean, E. (2012) Cardiovascular and Pulmonary physical therapy: Evidence to practice (5th ed.). Missouri: Mosby.

Gang, A \& Ikiz, A. (2013). Efect Of Deep Breathing Exercises On Oxiygenatype After Head And Nect Surgery. Elsevier Mosby.

Herliawati. (2012). The Influence of a Spiritual Approach to the Level of Loneliness in the Elderly in the Tama Community PSTW, Timbangan Village, Indralaya Utara District. http: //pustaka.unsri Retrieved August 10, 2016.

Izma Daud, Muthmainnah. 2018. Comparison of Guided Imagery Therapy with Slow Deep Breathing Relaxation in Reducing the Pain Scale of Post Laparatomy Patients in the RSUD Ulin Surgery Room, Banjarmasin in 2017. ISSN: 2580-0078. Vol. 2 No. 1 (June, 2018)

JNC-7, 2010. The Seventh Report Of The Joint National Committee On Prevention Detection, Evaluation And Treatment Oh High Blood Pressure. http://www.nhbl.nih.gov/guidelines hypertension / jnc7full.pdf (Accessed October 2019). 